\title{
Students' Capabilities in Designing A Mathematics Lesson Plan (RPP) Based on Islamic Values
}

\author{
Asep Jihad, Yayu Nurhayati Rahayu, Ida Nuraida \\ UIN Sunan Gunung Djati Bandung \\ Bandung, Indonesia \\ asjiead2006yahoo.co.id, yayunurhayatirahayu@uinsgd.ac.id, idanuraida@uinsgd.ac.id
}

\begin{abstract}
Research on the development of Mathematics Education students' ability in designing the lesson plan of math based on religion (Islam) is motivated by the fact that the students who follow the micro teaching course besides have the ability to teach, also have to be able to make the lesson plan. The context of mathematics material in lesson planning is demanded to be based on Islamic values in accordance with the vision of State Islamic University Sunan Gunung Djati Bandung. This study aims to analyze the students' ability in preparing the lesson plan of Mathematics based on Religious values (Islam), as well as the attitude of the students of the subjects related to the planning of religious-based mathematics learning (Islam). The results of the analysis are used as data to design the lecture model in Mathematics Education study program to be able to collaborate between subjects of Mathematics content, teacher's subjects and religious subjects. The method used in this research is Research and Development ( $R \& D)$. This research attempts to conduct evaluative studies on the product of Islamic-based lesson plan made by the students, as well as making the model design of lectures on the Mathematics Education study program.
\end{abstract}

Keywords-mathematics; Islam

\section{INTRODUCTION}

According to Nanat, UIN Sunan Gunung Djati's vision of "Revelation Guiding Science" implies its implementation of Islamic views into life attitudes and life skills [1]. One indicator is having a high commitment to the teachings of Islam. The visible evidence of the vision is evident from the development of scholarship throughout the Faculty including graduates of Tarbiyah and Teachers Faculty who make Islamic values as the basis for scientific development and learning practices. This vision can encourage the formation of additional competencies on UIN Bandung graduates who become the superior. The graduates have general scientific competence based on Islamic values in an integrated manner; there is no dichotomy between the religious science and the general science in all learning process.

Educational activities with revelation-based guiding science can encourage the transformation and integration of Islamic values in the development of knowledge and learning. The process of transformation and integration of science and learning encourages its passage to make Islamic value as a step for developing knowledge. The implementation is by designing a planning model with revelation-based guiding science. Learning planning model in its implementation is an effort to apply Islamic value to lesson planning program for non-Islamic Education Study Program [2].

Mathematics education is a general study program in the Faculty of Tarbiyah and Teacher Training UIN Bandung, competence of the graduates is having the skills to become educators at the basic and secondary level for the field of mathematics without leaving the values of Islam. Therefore, in lectures, lecturers must equip students with the competence of Islamic values Tafsir said that in order to implement the vision and program of revelation guiding science need to be formulated clearly how the value of Islam in the program and practice of learning in all study programs within the Faculty of Tarbiyah and Teacher Training.

Implementation of Islamic values in the learning process is expected to generate awareness of the learners, that science is part of Islam which comes from Allah SWT. Science learning that awakens to the value of goodness and salvation will create the good of human beings. Learning that contains both good and salvation in relation to the Almighty in the form of noble character. Along with that it is known that learning mathematics subjects is used as tools, mindset, and science or knowledge. The three functions of mathematics should be used as a reference in school math learning.

Several studies have revealed that IMTAQ-based science learning program will encourage an understanding of the integration of Islamic values and integrated values through science learning [3]. The value of the religion of Islam (spiritual) encourages a learning process to be important (useful), good (true) that comes from the Quran is a value that motivates the growth of belief and obedience to worship Him.

Based on the above description, the researcher formulates the problem essentially as follows; 1) How is the model of mathematics learning that integrates Islamic values for students of mathematics education study program ?; 2) What is the competence of students of mathematics education study program in integrating Islamic values in mathematics materials in planning the implementation of mathematics learning? 3) How do students of mathematics education study program respond to the implementation of integration of Islamic values in mathematics learning?

This study aims to: (1) develop a model of mathematics learning that integrates Islamic values for students of mathematics education study program, (2) finds a picture of 
competence of mathematics education study program in integrating Islamic values in mathematics materials in planning the implementation of learning mathematics, 3) get feedback from lecturers and students on mathematics learning development program in integrating Islamic values on mathematics material.

\section{A. Lecture Model}

Model or lecture pattern is the main aspect in creating the strengthening of education process in university. The learning experience that is shared by the students during the lectures plays a role in the formation of ability and determines the quality of the lecture.

Student involvement in the lecture is needed, because there are still many students who have different views about the concepts they learned before with scientific concepts, for example with the concept of mathematics [4]. In addition, most students still have difficulty in learning, especially students in the first year. Although hundreds of books have been published, maybe even thousands, yet they still have difficulty in learning [5].

One effort that can be done is to design a lecture that incorporates the assessment component, student involvement, problem solving, critical thinking, and collaborative missions [6]. Learning that has such characteristics, can be designed as a product-based lecture with the guidance of lecturers.

According to Arends lecture strategy is very influential on the interest, motivation, and even the perception of students to the course [7]. Designed lecture strategies must be innovative, empower students, and student centered. The facts in the field are still not contextual, the delivery method is monotonous, lacking optimal media utilization, interest, initial ability, and the students' needs are not accommodated. As a result, students' mastery and understanding of the concepts is relatively weak [8].

Various reform efforts in the field of learning continue to be done by LPTK through programs coordinated by the Directorate General of Higher Education, such as training lecturer field of PMIPA LPTK, Action Research, Semi-Que, and Lesson Study. Furthermore, Dikti explained that the program implemented by Dikti is an effort to improve lectures that lead to student-centered learning-oriented to provide a challenging and fun learning experience. Furthermore, students are expected to be familiar with the deep approach and strategic approaches in learning, not just learning to remember information. The next step is to make the product of the lecture, one of which can be in the form of making the lesson implementation plan (RPP).

\section{B. Competences of Graduates of Mathematics Study Program in Developing Religious Mathematics Learning Plan (Islam)}

According to Fajar, qualified graduates (output) of higher education institutions are the responsibility of educational institutions, especially in preparing scholars who play a role in displaying his superior strength, creative, independent and professional in their respective fields [9]. A graduate of a department must master the area of expertise and master the competencies expected by the department, for example a religion teacher education graduate must have the ability to teach appropriately and well about religious education in school. The competence of this area of expertise is determined, planned and developed by the department. Majors need to determine what main competencies should be mastered by students of religion education, so that their graduates can be called qualified graduates [10].

Ministry of National Education Decree Number 045 / U / 2002, on Higher Education Core Curriculum defines competence as a set of intelligent actions, full of responsibilities possessed by a person as a condition to be deemed capable by the community in performing certain tasks in the field of work. A graduate is considered competent in a particular field if he is able to demonstrate responsible acts in the field, thus earning the trust of the community. Smart and responsible action, which is a very complex decision-making act, is based on a variety of capabilities, which in the Decree of the Minister of National Education no. 045 / U / 2002 referred to as the element of competence, which consists of: 1) the basis of personality; 2) mastery of science and skills; 3 ) the ability to work; 4) attitudes and behaviors in the work according to the level of expertise based on the knowledge and skills mastered, and; 5) understanding the rules of community life in accordance with the choice of expertise in the work.

The success of Mathematics Education Study Program in Tarbiyah Faculty of UIN Sunan Gunung Djati Bandung is creating a professional teacher who keeps the mission of UIN Sunan Gunung Djati as a general scholar based on religion. One of the students' competence parameters is their ability to formulate the lesson plan (RPP), because the lesson planning includes curriculum review activities, syllabus forming, learning strategies, learning resources used and the unit of learning activities is actually the most important thing because planning is the foundation of the implementation which is conducted [11]. Students of Mathematics Education Study Program UIN Bandung need to have competence in making Islamic value-based planning as one of the characteristics and is the vision of UIN Sunan Gunung Djati.

RPP is a very important step before the implementation of learning. Careful planning is required for effective implementation of learning. Learning planning is incorporated into the Lesson Plans (RPP) or some other terms such as instructional design or learning scenarios. RPP contains Core Competencies (KI), Basic Competencies (KD), indicators to be achieved, materials to be studied, learning methods, learning steps, learning media, and learning resources and assessment.

Government Regulation Number 19 Year 2005 on 8 National Standards of Education states that learning planning includes Syllabus and RPP. At Curriculum 2013 Syllabus has been created by the government and RPP is developed by teachers in educational units.

The first stage in learning according to the process standard is learning planning that is realized with the activities of the preparation of lesson plan (RPP). RPP includes: (1) school data, subject matters, and class / semester; (2) main topic; (3) time allocation; (4) learning objectives, KD and indicators of 
achievement of competence; (5) learning materials; learning methods; (6) media, tools and learning resources; (6) steps of learning activities; and (7) assessment. Characteristic of RPP which is made by students of mathematics education study program UIN Sunan Gunung Djati Bandung is to combine general science; in this matter is mathematics, with religious sciences integratively.

\section{METHOD}

This research uses research and development. This research is aimed to develop the learning program of Mathematics based on Islamic values to improve the ability of prospective teachers in integrating Islamic values and Mathematics values.

The research was carried out on Mathematics Education Study Program in Tarbiyah Faculty of UIN Sunan Gunung Djati Bandung, for Micro Teaching and Mathematics Learning Planning Courses. To obtain complete data in conducting data analysis and data processing, then several methods of data collection are used, namely as follows: 1) Observation; 2) Interview; and 3) Documentation.

\section{FINDINGS AND DISCUSSION}

Research is done through two stages namely the designing stage and the dissemination stage.

\section{A. Designing}

At this stage, the text of religious-based (Islamic) learning planning is produced to create the draft according to the sequence in accordance with the instruction of making the lesson planning for several meetings. The draft is then submitted to specialists who specialize in the field for review. Selected experts are those who understand about the concept of curriculum, the concept of mathematical material and experts in terms of Islamic science.

Expert assessment is used to examine Islamic-based learning planning. Validation aims to obtain the recognition or validation of the conformity of the learning plan with the existing structure in the existing curriculum and syllabus, so it is feasible and suitable for use in learning. When the results of the assessment on the product test meet the standards, then the product of Islamic-based learning planning can be utilized in the field on learning activities.

\section{B. Dissemination}

The process of dissemination is a final stage of development. The dissemination stage is carried out to promote the development of Islamic-based learning plans in order to be accepted by users, whether individuals, groups or systems. Dissemination will be done in other classes with the aim to notice the effectiveness of its use in the learning process.

\section{Analysis of the Result of Validation of Islamic Based Learning Plan}

Description of the validation result of Islamic-based mathematics learning is validated by 3 people to assess the feasibility of lesson planning. Table 1.1 presents the results of validation of the product of planning of mathematics learning based on religion (Islam). 
TABLE I. ANALYSIS OF VALIDATION RESULT OF ISLAMIC-BASED MATHEMATICS LEARNING

\begin{tabular}{|c|c|c|c|c|c|}
\hline No & Rated aspect & Validator 1 & Validator 2 & Validator 3 & Average \\
\hline \multirow{6}{*}{ I } & Format of Islamic-Based Mathematics Learning Planning & & & & \\
\hline & a. Clarity of material selection for Mathematics Learning Planning & 4 & 4 & 4 & 4 \\
\hline & b. Sequence system in developing Mathematics Learning Planning & 3 & 4 & 4 & 3.67 \\
\hline & c. Typing clarity in preparing Mathematics Learning Planning & 4 & 3 & 4 & 3.67 \\
\hline & $\begin{array}{l}\text { d. Conformity in choosing Islamic materials and values for } \\
\text { Mathematics Learning Planning }\end{array}$ & 4 & 4 & 3 & 3.67 \\
\hline & Total average & & & & 3.75 \\
\hline \multirow{5}{*}{ II } & Language Use & & & & \\
\hline & a. Grammar conformity in preparing Mathematics Learning Planning & 3 & 4 & 4 & 3.67 \\
\hline & $\begin{array}{l}\text { b. The simplicity of sentence structure in Mathematics Learning } \\
\text { Planning }\end{array}$ & 4 & 3 & 3 & 3.33 \\
\hline & c. Communicative language selection & 4 & 4 & 4 & 4.00 \\
\hline & Total average & & & & 3.67 \\
\hline \multirow{7}{*}{ III } & Material Selection & & & & \\
\hline & $\begin{array}{l}\text { 1. Truth in composing the Structure of Mathematics Learning } \\
\text { Planning }\end{array}$ & 4 & 3 & 3 & 3.33 \\
\hline & $\begin{array}{l}\text { 2. Content validity of Mathematics Learning Planning between } \\
\text { Mathematics and Islamic Values }\end{array}$ & 4 & 4 & 4 & 4.00 \\
\hline & 3. Clarity and sequence of Mathematical presentation & 3 & 3 & 4 & 3.33 \\
\hline & 4. Compatibility with the syllabus & 4 & 3 & 4 & 3.67 \\
\hline & 5. Conformity with the learning model used & 4 & 4 & 3 & 3.67 \\
\hline & Mean & & & & 3.60 \\
\hline \multirow[t]{5}{*}{ No } & Rated Aspect & Validator 1 & Validator 2 & Validator 3 & Average \\
\hline & Total average & & & & 3.67 \\
\hline & Total score & 93.8 & 89.6 & 91.7 & \\
\hline & Percentage & $93,8 \%$ & $89,6 \%$ & $91,7 \%$ & \\
\hline & Percentage average & $91.66 \%$ & & & \\
\hline
\end{tabular}

Based on Table 1, it is obtained the average in the aspect of Format of Islamic-Based Mathematics Learning Planning of 3.67 (good), aspects of language use of 3.73 (good) and aspect of material choosing of 3.83 (good), while the validation percentage of Islamic-based Mathematics Learning Planning of $93.6 \%$. When it is adjusted to the table of fit/feasibility that has been established then it is in good qualification (80-89) so that the product of Islamic-based Mathematics Learning Planning can be utilized in the actual field for learning activities/no revision.

Suggestions from the validators for the Islamic-based Mathematics Learning Planning are reproduced and tested. The following is presented in the diagram of the result of the material validation test in Figure 1.
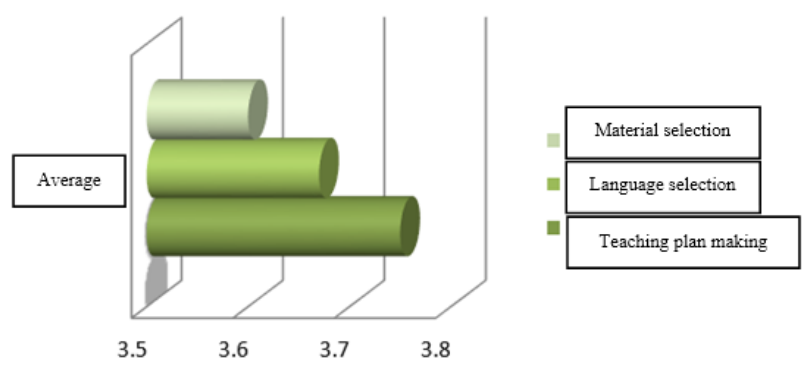

Fig. 1. Result of validation test.
Meanwhile, to find out the attitude of students to the implementation of the lecture is given a questionnaire. Through this questionnaire, students are asked to express their opinions and attitudes towards the implementation of lectures that encourage students to be able to make Islamic-based Mathematics Learning Planning. In addition, through the questionnaire will also be selected whether students provide feedback on the implementation of the lecture.

Based on the result of questionnaire of student response given to all students, obtained the result of analysis that lectures conducted by lecturers in encouraging students to make the planning of mathematics learning based on Islamic religion belongs to good category, this is seen from the student response when they are asked about "whether lectures encourage students to integrate the value of Islam and mathematics in making learning plans?", 78\% said very helpful, $15 \%$ said helpful, $4 \%$ said helpful enough, and $3 \%$ said less helpful. For the question "does the problem presented in the course help your understanding in making an Islamic-based Mathematics Learning Planning?" 86\% said it was helpful, $11 \%$ said helpful and 3\% said it was helpful. The statement "how is the guidance given to design the planning of Islamicbased mathematics learning?" $15 \%$ said very well, $73 \%$ said well, $12 \%$ said quite well. Whereas in the question "is the description of the guidance on the structure of the making of the Islamic-based Mathematics Learning Planning presented in 
the lecture easy to understand?", $80 \%$ said very easy to understand, $16 \%$ said easy to understand and $41 \%$ said quite easy to understand.

\section{CONCLUSION}

Based on the results of the study, it can be concluded that students have adequate ability in making the Islamic-based Mathematics Lesson Plan very well. This is seen from the products made by the students after the experts' validation. This capability arises as an implication of lectures by lecturers to help improving students' ability in planning. Student attitude is in a good category. This implies that UIN's vision of revelation guiding science must be implemented in an integrated manner in the lecture.

\section{REFERENCES}

[1] N. F. Natsir, Tranformasi IAIN Menjadi UIN Menuju Research University, Gunung Djati Press, 2008, pp. 12.

[2] T. Ahmad, Filsafat Pendidikan Islami; Integrasi Jasmani, Rohani dan Kalbu Memanusiakan Manusia, cetakan pertama. Jakarta: Remaja Rosdakarya, 2007, pp. 74.
[3] B. Dwi, Implementasi Kurikulum Konsep dan Penarapan. Surabaya: Kata Pena, 2008, pp 2.

[4] V. de Watering and Gonen,'Students'assessment preferences, perceptions of assessment and their relationship to study results". High Education, 2008, pp 95.

[5] Subroto, Implementasi Model Perkuliahan Berbasis Tes Untuk Mengukur Kemampuan Mahasiswa Dalam Menyelesaikan Soal Terpadu Berbentuk "Pilihan-Uraian" Pada Mata Kuliah Mekanika Analitik, Jurnal UNY Vol. II No. 11, 2007, pp 1.

[6] A. Yadav, "Teaching Science with Case Studies" Journal of Colledge Teaching. 2007, pp. 17

[7] R.I. Arends, Learning to Teach. New York: MC Grow Hill. Inc 2004.

[8] Dikti. Pembelajaran Inovatif \& Partisipatif. Jakarta: Direktorat Ketenagaan Direktorat Jenderal Pendidikan tinggi Departemen Pendidikan Nasional. 2007

[9] F. Malik, Visi Pembaharuan Pendidikan Islam, Jakarta: Alfa Grafika Utama, 1998, pp. 95

[10] M. Darwis, Kompetensi lulusan fakultas tarbiyah Dalam menghadapi pasar global Jurnal Ilmiah Didaktika Agustus Vol. XII No. 1, 2011, pp. 123-133.

[11] Khaerani, peningkatan kompetensi guru dalam menyusun RPP melalui kegiatan IHT (In House Training) Jurnal Penelitian Tindakan Vol. 17, No. 1, Januari 2016. 